\title{
PELATIHAN BAHASA INGGRIS KOMUNIKATIF UNTUK KELOMPOK KERJA "SERANGAN TRANSPORT" DI DESA ADAT SERANGAN
}

\section{ENGLISH COMMUNICATIVE PRACTICE FOR "SERANGAN TRANSPORT” TEAM WORK IN SERANGAN VILLAGE}

\author{
1)IGA Vina Widiadnya Putri ${ }^{2)}$ I Dewa Ayu Devi Maharani Santika, ${ }^{3)}$ Komang Dian Puspita C \\ ${ }^{1,2,3)}$ Program studi Sastra Inggris, Sekolah Tinggi Bahasa Asing Saraswati Denpasar \\ Jl. Kamboja no 11x Denpasar \\ ${ }^{1)}$ vina.ayu422@gmail.com ${ }^{2)}$ devimaharani17@gmail.com ${ }^{3)}$ miss_puspita@yahoo.com
}

\begin{abstract}
ABSTRAK
Desa Adat Serangan merupakan salah satu desa yang berada di Kecamatan Denpasar Selatan, Bali.Desa Adat Serangan memiliki potensi yang sangat kuat untuk menjadi desa wisata karena didukung oleh pesona alam dan nilai-nilai sosial budaya sebagai destinasi wisata yang maju seiring dengan kemajuan destinasi pariwisata sekitarnya.Dalam menyukseskan hal tersebut, tidak dapat dipungkiri bahwa Bahasa adalah salah satu aspek yang harus dikuasai, karena bahasa merupakan sarana dalam berkomunikasi dan kenyataan dilapangan tidak semua kelompok kerja dapat berbicara dengan menggunakan bahasa Inggris yang komunikatif, salah satunya kelompok penyedia jasa transportasi yang dikenal dengan sebutan "Serangan Transport. Tujuan dari pelaksanaan kegiatan pengabdian di Desa ini untuk meningkatkan kemampuan berbahasa Inggris kelompok kerja "Serangan Transport" agar lebih komunikatif.Kegiatan pengabdian fokus pada kegiatan pelatihan bahasa Inggrisdengan materi yang disesuaikan dengan kebutuhan komunikasi kelompokdan metode pengajaran yang disesuaikan dengan kebutuhan kelompok "Serangan Transport". Diharapkan dari pelatihan ini, dapat meningkatkan kemampuan berbahasa Inggris para penyedia jasa transportasi agar lebih komunikatif dalam berkomunikasi dengan tamu asing yang tentunya akan berdampak pada keberhasilan pihak desa menjadikan Desa Adat Serangan menjadi Desa Wisata Bahari. Metode yang digunakan dalam kegiatan pengabdian masyarakat yang dilakukan di desa Serangan adalah metode ceramah dan diskusi yang fokus pada kegiatan pelatihan bahasa Inggris untuk kelompok sasaran yaitu kelompok kerja "Serangan Transport" di desa Serangan. Berdasarkan hasil evaluasi dari masing masing peserta pelatihan, menunjukan bahwa beberapa peserta mendapatkan nilai baik dan sebagian lainnya mendapatkan nilai yang sangat baik.Sehingga dapat dikatakan bahwa peserta pelatihan dinilai telah mampu mengikuti dan memahami materi - materi yang diberikan dalam pelatihan bahasa Inggris ini.
\end{abstract}

Kata Kunci: Pelatihan, Bahasa Inggris, Serangan, Desa Wisata, Kelompok Transport

\section{ABSTRACT}

Serangan Village is one of the villages in South Denpasar, Bali. This village was located in an island called Serangan Island which was parted from the main island. This village has a great potential to be a tourist village and becoming a flourishing tourist destination which is not inferior to the other destinations since it is supported by the enchanment of its nature and the socio - cultural values. In succeeding this, it cannot be denied that mastering English language is a very important aspect because language is an equipment to communicate,but the fact is not all of the team works have the fluency in spoken English. One of them is the transportation team work called 'Serangan Transport". The aim of having this community service in the village, peculiarly in this transportation team work, is to increase the competence in using communicative English. The activities of this community service are focused on the communication needs and the method of teaching the language which is suitable for the team work activities.It was expected that through this course, the English language ability of this team work is increasing, in order to be more communicative when having the conversations with foreign tourists. 
This certainly will give influences to the success of forming the Serangan village as the nautical tourist village. The method that used in this program is explanation and discussing focused to larning English in communication for the team work in Serangan village. Based on the result of the evaluation shown that some of the members have got good value and some another got the best value. So it means that program has been success and the members have understood about the English comunication leason.

Key Words: English Language Course, Serangan, Tourist Village, Transportation team work

Submited: 27 Agustus 2017 Revision : 26 Februari 2018 Accepted : 6 Maret 2018

\section{PENDAHULUAN}

Berdasarkan letak geografis kota Denpasar, desa adatSerangan adalah sebuah desa yang berada di Kecamatan Denpasar Selatan, Bali, yang letaknya sekitar 10 kilometer ke arah Selatan dari pusat kota Denpasar. Dulunya desa initerletak disebuah pulau kecil yang hanya menyisakan pesisir pantai yang sempit dan merupakan sebuah pulau yang terpisah dengan daratan Pulau Bali, tapi saat ini telah dilakukan reklamasi sehingga keberadaan pulau ini menyatu dengan pulau Bali. Desa ini dikelilingi pohon mangrove yang tampak indah dan menyejukkan mata bagi para pengunjung yang berada di pintu gerbang kawasan ini.Hamparan pantai dan laut yang biru sangat menarik perhatian wisatawan untuk berkunjung ke pulau Serangan. Mata pencaraharian masyarakat terbagi menjadi dua kelompok kerja, sebagian masyarakat masih mewarisi keahlian nenek moyang dengan menjadi Nelayan, dan sebagian diantaranya sudah melirik ke sektor pariwisata yang mulai dikembangkan seperti: water sport, jasa trasportasi, dan konservasi penyu.

Desa Adat Serangan memiliki potensi yang sangat kuat untuk menjadi desa wisata karena desa ini didukung oleh pesona alam dan nilai-nilai sosial budaya sebagai destinasi wisata yang maju seiring dengan kemajuan destinasi pariwisata sekitarnya.Desa Adat Serangan memiliki kedudukan yang strategis karena berada di antara "Segitiga Emas" destinasi Pariwisata Bali yaitu Kawasan Sanur, Nusa
Dua dan Kuta.Selain itu, sebagian wilayah Desa Adat Serangan saat ini dikelola oleh Bali Turtle Island Development (BTID) sehingga Desa Adat Serangan saat ini lebih dikenal dengan sebutan"Turtle Island".Dengan demikian tampak jelas bahwa Pihak Desa dibantu oleh pemerintah Provinsi Bali sedang gencar melakukan pengembangan di Desa ini.Pengembangan Desa Adat Serangan menjadi desa wisata membutuhkan bantuan secara maksimal dari seluruh pihak, dan tetap peranan masyarakat lokal berada diurutan paling atas.

Secara umum permasalahan prioritas yang dihadapi masyarakat Desa Adat Serangan yang berkecimpung dalam sektor Pariwisata adalah rendahnya kualitas komunikasi Bahasa Inggris.Hal ini disebabkan karena kurangnya pemahaman teori dan motivasi masyarakat untuk meningkatkankemampuanberbahasa Inggris yang mereka miliki. Berdasarkan data kependudukan kecamatan setempat terhitung sampai tahun 2017, hampir 87\% masyarakat desa Serangan hanya mengenyam pendidikan sampai ditingkat sekolah menengah atas(SMA), dan 23\% sisanya berpendidikan dengan tingkat Sarjana dan pendidikan magister(S2) namun setelah ditelaah lebih jauh bidang ilmu yang ditekuni bukanlah bidang ilmu Bahasa dan Pariwisata.

Pemilihan Desa Adat Serangan untuk lokasi pelaksanaan kegiatan pengabdian masyarakat didasari atas potensi Desa Adat Seranganuntuk menjadi desa wisata dengan melihat pada sektor 
pariwisatayang cukup baik namun belum memiliki sumber daya manusia yang memadai.Hal ini disebabkan karena indikator tingkat pendidikan masyarakat yang rendah. Sementara pemilihan kelompok kerja“'Serangan Transport”untuk menjadi mitra pada kegiatan pengabdian masyarakat ini adalah melihat prospek keberadaan dari"Serangan Transport"yang sangat menunjang keberhasilan pengembangan desa menjadi desa wisata karena kelompok kerja ini bersentuhan langsung dengan para wisatawan.Tujuan dari kegiatan pelatihan bahasa inggris ini adalah untuk memberikan bekal pengetahuan kepada masyarakat dalam berkomunikasi dengan bahasa Inggris.Diharapkan dengan dilaksanakannya pelatihan bahasa Inggris komunikatif, masyarakat desa Serangan dapat meningkatkan kemampuan mereka dalam berkomunikasi menggunakan bahasa Inggris kepada wisatawa.

\section{METODE}

Kegiatan pengabdian masyarakat yang dilakukan di desa ini fokus pada kegiatan pelatihan bahasa Inggris untuk kelompok kerja "Serangan Transport" yang saat ini kemampuan bahasa Inggrisnya masih tergolong rendah. Prosedur yang dilakukan untuk penyelesaian permasalahan yaitu:

1. Melakukan survei untuk mengetahui frekuensi penggunaan bahasa Inggris oleh masyarakat lokal yang tergolong dalam kelompok "Serangan Transport"

2. Menyiapkan materi bahasa Inggris yang sesuai dengan hasil survei sebelumnya

3. Menentukan metode pelatihan yang tepat

4. Mengevaluasi hasil pelatihan

5. Pendampingan kelompok "Serangan Transport" setelah pelatihan selesai diberikan

\section{HASIL DAN PEMBAHASAN}

Kegiatan pengabdian masyarakat dengan program pelatihan Bahasa Inggris di Desa Adat Serangan memberikan pendekatan dan penawaran kepada masyarakat untuk dapat berkomunikasi dengan baik kepada wisatawan.Solusi yang ditawarkan dan dilakukan adalah dengan memotivasi masyarakat untuk mengikuti pelatihan Bahasa Inggris agar dapat langsung dipersiapkan dalam menghadapi dunia pekerjaan yang digelutinya yaitu sektor pariwisata.

Prosedur penyelesaian permasalahan yang dilakukan secara umum antara lain sebagai berikut:

1. Memberikan kuesioner kepada masyarakat untuk mengetahui kebutuhan bahasa Inggris oleh kelompok kerja "Serangan Transport"

2. Mempersiapkan materi yang akan diberikan kepada masyarakat terkait dengan kebutuhan dan kompetensi Bahasa Inggris yang sering digunakan.

3. Melakukan pelatihan Bahasa Inggris dengan beberapa pendekatan kepada masyarakat disesuaikan dengan tingkat usia dan pendidikan masyarakat.

4. Mengevaluasi hasil pelatihan dan memberikan penilaian secara objektif terhadap setiap kegiatan.

5. Pemberian modul Bahasa Inggris bagi masyarakat.

Susilofy (2010) menyampaikan bahwa aktivitas belajar siswa merupakan segala kegiatan yang dilaksanakan baik secara jasmani atau rohani selama proses pembelajaran berlangsung. Kegiatan pelatihan Bahasa Inggris ini dilakukan selama sepuluh kali pertemuan dibedakan menjadi delapan kali materi dan dua kali evaluasi, evaluasi pertama dilakukan setelah pertemuan keempat dan evaluasi kedua dilakukan setelah pertemuan 
kedelapan.Evaluasi akhir bertujuan untuk mengetahui tingkat kemahiran peserta pelatihan dalam menguasai Bahasa Inggris yang sudah diajarkan.Di akhir petemuan telah dibagikan kuesioner yang bertujuan untuk mengetahui tingkat kepuasan peserta pelatihan selama mengikuti pelatihan.Pemberian materi dilakukan dengan bervariasi. Materi-materi yang diberikan sebagai berikut:

1. Pertemuan pertama, dengan memberikan materi greeting, polite expression dan identifikasi pronunciation dan kesalahannya.

2. Pertemuan kedua, dengan memberikan materi tentang Asking and offering for assistance (English for specific purpose in transportation)

3. Pertemuan kedua, dengan memberikan materi tentangAsking and giving price (English for specific purpose in transportation)

4. Pertemuan keempat, dengan memberikan materi tentangHandling reservation

5. Pertemuan kelima, dengan memberikan materi tentangHandling complaint

6. Pertemuan keenam dengan memberikan materi tentangHandling guest service

7. Pertemuan ketujuh dan Kedelapan dengan memberikan materi tentangItinerary

Menurut Kurnia (2013), yang mengutip pendapat Barak Roseshine dalam Suhardan (2010) mengajar yang efektif merupakan sebuah tindakan guru yang terlatih dalam melaksanakan pekerjaannya yaitu kemahiran dalam menyajikan bahan pelajaran dengan meramu berbagai penggunaan metode mengajar untuk menyajikan materi.Kurnia (2013) menggunakan model pembelajaran berkelompok yang disebut snowball throwing, hanya saja materi yang digunakan berhubungan dengan penerapan sikap siswa didiknya dalam kehidupan sehari-hari.Sementara metode pengajaran yang tepat dilakukan dalam kegiatan pengabdian ini yaitu metode cooperation dan question for clarificationyang materinya disusun berdasarkan kebutuhan kerja peserta didik.Cooperation adalah metode belajar dengan berkelompok sehingga memperoleh feedback dan model aktifitas berbahasa dari rekan-rekan kelompoknya.Sedangkan question for clarification digunakan agar peserta pelatihan dapat bertanya kepada guru sehingga dapat mengulang, menjawab bahkan menjelaskan dan memberikan contoh dari kegiatan pembelajaran yang dilakukan.Metode ini diadopsi dari Brown (2000) dalam bukunya Principle Language Learning and Teaching. Metode pengajaran ini merupakan metode yang tepat digunakan dalam pembelajaran Bahasa pada usia dewasa karena dapat meningkatkan motivasi belajar peserta pelatihan dan dengan memberikan materi pembelajaran yang tepat guna, peserta pelatihan dapat dengan mudah memahami materi yang diberikan.

Sebelum pelaksanaan pelatihan, telah dilakukan survei dan quisioner kepada calon peserta pelatihan untuk mengetahui sejauh mana peserta pelatihan memahami dan menguasai Bahasa Inggris dalam melayani wisatawan.Survei tersebut juga bertujuan untuk mengetahui kemampuan peserta pelatihan dalam proses pembelajaran yang dilakukan. Survei kebutuhan peserta dilakukan dengan tiga data yaitu latar belakang pendidikan terakhir peserta, rentangan usia peserta pelatihan, pengalaman mengikuti pelatihan sebelumnya. Berikut adalah hasil survei kebutuhan peserta yang telah dilakukan.

1. Pendidikan Peserta Pelatihan 
IGA Vina Widiadnya Putri, I Dewa Ayu Devi Maharani Santika, Komang Dian Puspita C Pelatihan Bahasa Inggris Komunikatif untuk Kelompok Kerja "Serangan Transport"

di Desa Adat Serangan

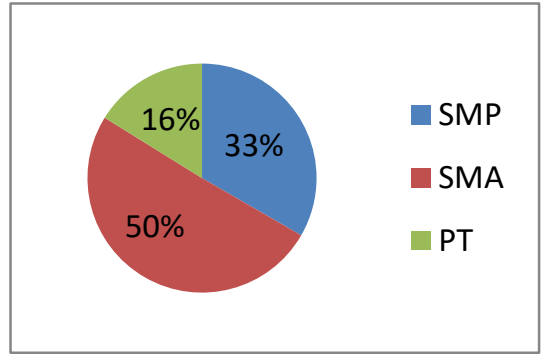

Gambar 1. Pendidikan terakhir peserta pelatihan

Pendidikan terakhir masyarakat Desa Adat Serangan adalah 50\% diantaranya adalah SMA dan 33\% diataranya adalah SMP dan $16 \%$ sisanya adalah Perguruan Tinggi. Latar belakang pendidikan ini, dapat menjadi acuan, sejauh mana masyarakat Desa Adat Serangan yang mengikuti pelatihan memahami pelajaran Bahasa Inggris dasar untuk berkomunikasi.Bahasa Inggris yang dipelajari di sekolah menengah umum, sudah menyisipkan materi Bahasa Inggris dasar yang hampir sempurna. Sehingga masyarakat Desa Adat Seranganyang 50\% pendidikan terakhirnya SMU bahkan Perguruan Tinggi seharusnya sudah mampu menggunakan Bahasa Inggris dasar dalam kehidupan sehari hari untuk melayani wisatawan. Namun dibalik semua itu, kelompok masyarakat Serangan transport cenderung menggunakan Bahasa Inggrisyang mudah dipahami namun kurang baku dalam struktur gramatikal Bahasa Inggris, contohnya: The price to Uluwatu is two fifty. Kalimat tersebut mengandung makna "harga transportasi ke Pura Uluwatu adalah dua ratus lima puluh ribu. Dalam Bahasa Inggris dua ratus lima puluh ribu adalah two hundred and fifty thousand. Kesalahan-kesalan pengucapan atau pronunciation juga sering terjadi ketika masyarakat memberikan penjelasan kepada wisatawan contoh: It pik price, maksud dari ujaran tersebut adalah harga ini tidak dapat ditawar. Dalam pengucapan Bahasa Inggris pik adalahfix.
Melalui pelatihan Bahasa Inggris ini, kesalahan-kesalahan yang awalnya menjadi sebuah kebiasaan dalam komunikasi sudah mulai dirubah ke ujaranujaran baku Bahasa Inggris. Materi-materi yang dibahas dan dirancang disesuaikan dengan materi guiding sebagai dasar komunikasi.Selanjutnya, pemberian hibah berupa modul Pelajaran Bahasa Inggris juga salah satu program yang diharapkan dapat berguna dan bermanfaat bagi masyarakat.

2. Rentangan UsiaKelompok Serangan Transport Peserta Pelatihan Bahasa Inggris

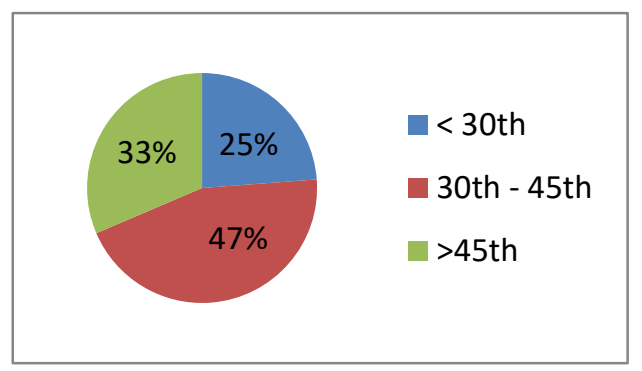

Gambar 2. Rentangan Usia Peserta Pelatihan

Rentangan usia peserta pelatihan di Desa Adat Serangan didominasi dari usia 30 tahun sampai dengan 45 tahun. Dari data ini, masyrakat Desa Adat Serangan yang mengikuti pelatihan adalah usia produktif. Rentangan usia tersebut, dapat memberikan gambaran terkait dengan motivasi peserta dalam mengikuti pelatihan. Masyarakat Desa Adat Serangan yang tergabung dalam Serangan transport merupakan masyarakat yang berada pada usia dewasa. Berdasarkan faktor usia, pembelajaran berupa pelatihan perlu dipahami beberapa pendekatan. Pendekatan tersebut dapat menjawab beberapa pertanyaan berikut ini: apa pendorong bagi orang dewasa dan usia 
lanjut untuk belajar, apa hambatan yang dialaminya, apa yang diharapkannya, bagaimana ia dapat belajar dengan baik dan sebagainya. Pemahaman terhadap perkembangan kondisi psikologi orang dewasa dan usia lanjut tentu saja mempunyai arti penting bagi para fasilitator dalam menghadapi orang dewasa dan para usia lanjut sebagai siswa atau peserta pelatihan.

Sardiman (2004) mengatakan bahwa motivasi belajar adalah faktor psikis yang bersifat non intelektual.Perlu ditumbuhkan gairah, merasa senang dan bersemangat untuk belajar.Kelompok masyarakat Serangan transport memiliki motivasi yang kurang dalam pengembangan ilmu pengetahuan dan tenologi. Berdasarkan jumlah kehadiran awal, hanya lima peserta pelatihan yang bersedia hadir dalam pemberian pelatihan Bahasa Inggris. Kemudian beberapa pendekatan digunakan untuk menumbuhkan motivasi peserta pelatihan dalam mengikuti pelatihan Bahasa Inggris.Pemberian materi disisipi dengan pemberian perubahan pola fikir.Kelompok masyarakat harus memiliki keinginan untuk belajar, harus siap untuk belajar, dan harus punya alasan untuk belajar. Jika peserta mempunyai motivasi yang kuat untuk belajar atau rasa keinginan untuk berhasil, dia akan lebih baik dibanding yang lainnya dalam belajar, karena motivasi dapat menciptakan lingkungan (atmosphere) belajar menjadi menyenangkan. Lingkungan belajar yang digunakan tidak terlalu formal tapi efektif, sehingga kelompok masyarakat Serangan transport dapat lebih memahami materi yang dibahas.

Dengan perubahan mind-set dan atmosphere yang menyenangkan, perubahan perilaku masyarakat tampak jelas perbedaannya.Menurut Gagne dalam Sagala (2010), belajar adalah suatu prosesdimana suatu organisme berubah perilakunya. Perubahan perilaku tersebut meliputi tiga ranahbelajar yakni ranah kognitif (pengetahuan), afektif(nilai dan sikap), dan psikomotorik (keterampilan). Kelompok masyarakat Desa Adat Serangan mulai membuka pemikirannya akan pentingnya pelatihan Bahasa Inggris dalam komunikasi, sehingga terjadi peningkatan kehadiranyang signifikan dalam mengikuti pelatihan, dimana hal ini merupakan bagian dari perubahan sikap mereka untuk menjadi terbuka terhadap pelatihan yang akan diberikan,

3. Pengalaman Mengikuti Kursus Bahasa Inggris

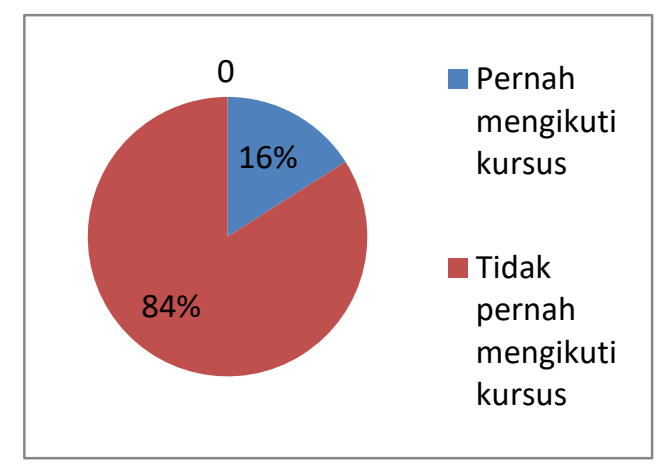

Gambar 3. Pengalaman mengikuti kursus

Sebagian besar masyaraat Desa Adat Serangan tidak memiliki pengalaman kursus Bahasa Inggris.84\% masyarakat tidak memiliki pengalaman dalam mengikuti pelatihan yang berkesinambungan. Hanya $16 \%$ sisanya yang pernah mengikuti kursus dan pelatihan Bahasa Inggris untuk menunjang cara berkomunikasi berbahasa asing. Tidak memiliki pengalaman kursus dapat mengakibatkan beberapa kesalahan yang dibiasakan. Kesalahan-kesalahan yang digunakan tidak dapat diperbaiki secara langsung sehingga akan menjadi pembiasaan yang buruk. Melalui pelatihan Bahasa Inggris ini, masyarakat dapat lebih memahami pentingnya pelatihan Bahasa Inggris yang berkesinambungan sehingga 
Bahasa Inggris yang digunakan dapat diucapkan dengan baik dan benar.

Pelaksanaan pelatihan Bahasa Inggris telah selesai diselenggarakan dan diakhiri dengan pembagian kuesioner kepuasan para peserta terhadap kegiatan pelatihan. Kuesioner ini dibagikan dengan tujuan untuk mengetaaahui manfaat pelatihan yang telah diberikan dan mengukur sejauh mana tingkat kenyamanan, kepuasan peserta dalam mengikuti pelatihan. Hasilnya sebagai berikut :

\section{Manfaat Materi Pelatihan}

Manfaat yang didapatkan dari pelatihan Bahasa Inggris ini berdasarkan hasil kuesioner dapat dijelaskan dari grafik dibawah ini:

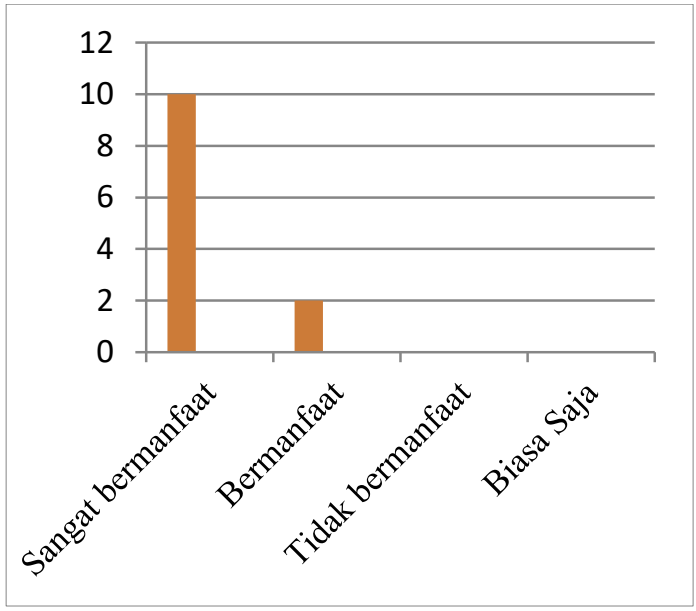

Gambar 4 : Manfaat materi pelatihan

Berdasarkan hasil kuisioner yang telah disebarkan maka dapat disimpulkan bahwa sebagian besar kelompok masyarakat Serangan transport menganggap program pelatihan dan pengabdian masyarakat ini sangat bermanfaat. Bahasa inggris yang telah diajarkan dapat digunakan sebagai alat dalam berkomunikasi bahasa Inggris dengan wisatawan.
2. Pemahaman Peserta terhadap Materi Pelatihan

Pemahaman peserta terhadap materi pelatihan Bahasa Inggris yang diajarkan, berdasarkan hasil kuisioner dapat dijelaskan dari grafik dibawah ini:

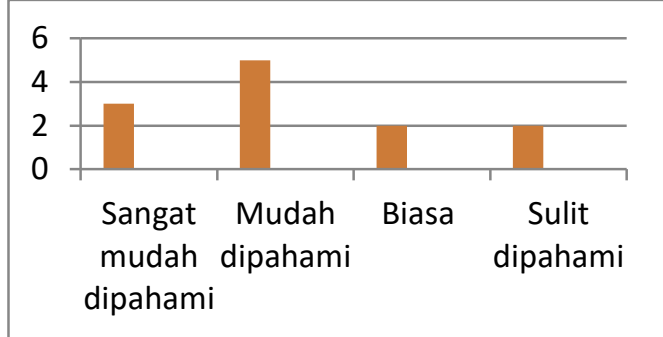

Gambar 5 : Manfaat materi pelatihan

Berdasarkan hasil kuesioner pemahaman peserta pelatihan Bahasa Inggris yang diajarkan merupakan materi yang dapat dengan mudah dipahami. Kelompok ini dapat lebih mudah memahami materi yang diajarkan karena materi yang disusun telah disesuaikan dengan kebutuhan mereka, terutama dalam pekerjaan yang mengharuskan mereka berkomunikasi menggunakan Bahasa Inggris yang komunikatif.

\section{Hasil Evaluasi}

Untuk mengukur sejauhmana tingkat keberhasilan pelaksanaa pelatihan, tidak hanya diukur dari kepuasan peserta namun juga terhadap evaluasi nilai dari peserta pada ujian pertama dan ujian akhir setelah selesainya penyelenggaraan pelatihan. Berikut adalah tabel yang menunjukan hasil evaluasi terhadap pelaksanaan pelatihan. 
Tabel 1. Hasil Evaluasi pertama Pelatihan Bahasa Inggris.

\begin{tabular}{clcc}
\hline No & Nama Peserta & Nilai & Predikat \\
\hline 1 & Made Sedet & 70 & Baik \\
\hline 2 & $\begin{array}{l}\text { Ketut Wira } \\
\text { Saputra }\end{array}$ & 75 & Baik \\
\hline 3 & Nyoman Narka & 74 & Baik \\
\hline 4 & I Wayan Sarma & 80 & $\begin{array}{c}\text { Sangat } \\
\text { Baik }\end{array}$ \\
\hline 5 & I Made Tantra & 73 & Baik \\
\hline 6 & $\begin{array}{l}\text { I Wayan } \\
\text { Budiartha }\end{array}$ & 74 & Baik \\
\hline 7 & $\begin{array}{l}\text { I Wayan } \\
\text { Ardana }\end{array}$ & 80 & Sagat Baik \\
\hline 8 & $\begin{array}{l}\text { I Nyoman } \\
\text { Suamba }\end{array}$ & 74 & Baik \\
\hline 9 & Putu Krisna & 73 & Baik \\
\hline 10 & Kadek Eka & 75 & Baik \\
\hline 11 & Miarta & 75 & Baik \\
\hline 12 & Made Jawin & 72 & Baik \\
\hline & & &
\end{tabular}

Tabel 2. Hasil Tes Akhir Pelatihan Bahasa Inggris.

\begin{tabular}{clcc}
\hline No & Nama Peserta & Nilai & Predikat \\
\hline 1 & Made Sedet & 75 & Baik \\
\hline 2 & $\begin{array}{l}\text { Ketut Wira } \\
\text { Saputra }\end{array}$ & 77 & Baik \\
\hline 3 & Nyoman Narka & 76 & Baik \\
\hline 4 & I Wayan Sarma & 85 & $\begin{array}{c}\text { Sangat } \\
\text { Baik }\end{array}$ \\
\hline 5 & I Made Tantra & 75 & Baik \\
\hline 6 & $\begin{array}{l}\text { I Wayan } \\
\text { Budiartha }\end{array}$ & 76 & Baik \\
\hline 7 & $\begin{array}{l}\text { I Wayan } \\
\text { Ardana }\end{array}$ & 85 & Sagat Baik \\
\hline 8 & $\begin{array}{l}\text { I Nyoman } \\
\text { Suamba }\end{array}$ & 77 & Baik \\
\hline 9 & Putu Krisna & 75 & Baik \\
\hline 10 & Kadek Eka & 77 & Baik \\
\hline 11 & Miarta & 78 & Baik \\
\hline 12 & Made Jawin & 76 & Baik \\
\hline
\end{tabular}

Berdasarkan tabel diatas dapat dilihat bahwa hasil evaluasi akhir peserta pelatihan menunjukkan kemampuan peserta dalam berbahasa Inggris memiliki predikat baik dengan range nilai antara 70 - 78. Sementara ada juga beberapa peserta yang memiliki kemampuan lebih dari peserta lain yang ditunjukkan dengan perolehan nilai evaluasi 85 yang memiliki predikat sangat baik. Sehingga dapat dikatakan bahwa peserta pelatihan dinilai telah mampu mengikuti dan memahami materi - materi yang diberikan dalam pelatihan bahasa Inggris ini.

\section{Dampak Modul}

Berdasarkan hasil kuisioner yang telah disebarkan, dampak modul yang diberikan kepada peserta pelatihan dapat dijabarkan melalui Gambar 6 di bawah ini:

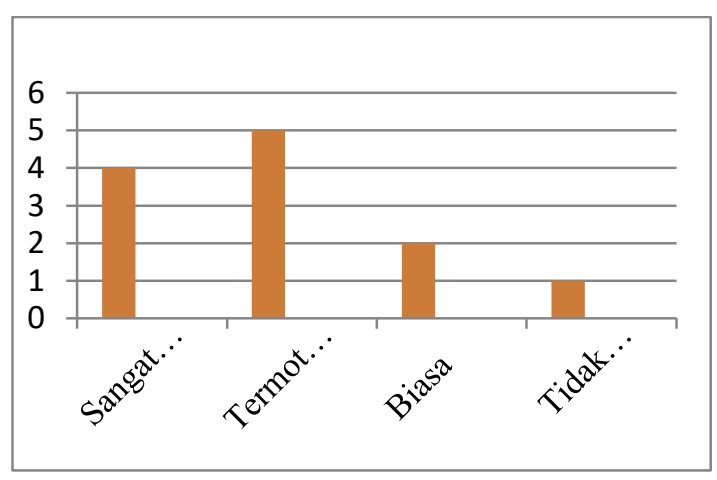

Gambar 6 : Dampak Modul

Modul yang diberikan kepada peserta pelatihan dapat meningkatkan motivasi peserta dalam mengikuti pelatihan. Sebagian besar peserta pelatihan dapat termotivasi dengan diberikannya modul sebagai penunjang proses pembelajaran. Modul memiliki beberapa manfaat bagi peserta pelatihan. Beberapa manfaat tersebut diantaranya dapat memperjelas dan mempermudah penyajian pesan agar tidak terlalu bersifat verbalistis (tanya jawab). Sehingga mampu mengatasi keterbatasan waktu, ruang, dan daya indera, baik bagi peserta didik maupun instruktur. Dengan disusunnya modul untuk peserta pelatihan dampak yang didapatkan adalah: (1)meningkatnya motivasi dan gairah belajar peserta didik, (2)kemampuan peserta didik dalam berinteraksi langsung dengan lingkungannya dan sumber belajar lainnya 
semakin baik, (3) memungkinkan peserta didik belajar mandiri sesuai kemampuan dan minatnya dan (4) memungkinkan peserta didik dapat mengukur atau mengevaluasi sendiri hasil belajarnya (self assesment).Sehingga, walaupun program pengabdian masyarakat ini sudah berakhir, masyarakat masih memperoleh dampak yang berkesinambungan dari pembelajaran yang sudah pernah dilakukan

\section{SIMPULAN}

Dari kegiatan pengabdian masyarakat yang telah dilaksanakan maka dapat disimpulkan bahwa pelaksanaan survei diawal kegiatan sangat membantu tingkat keberhasilan dari kegiatan pengabdian masyarakat yang dilakukan. Pertanyaan yang disertakan dalam survey adalah, tingkat pendidikan terakhir peserta, rentang usia peserta pelatihan dan pengalaman keikutsertaan peserta pada kursus bahasa Inggris sebelumnya. Berdasarkan hasil dapat dirancang model Pelatihan Bahasa Inggris yang sesuai untuk kelompok kerja "Serangan Transport". Metode pelatihan yang tepat dalam pelatihan ini adalah Sosioaffective strategy dengan mengadopsi metode cooperation dan Question for clarification.Hasil evaluasi akhir menyebutkan bahwa nilai yang diperoleh peserta berada di interval baik dan sangat baik.Kuesioner tentang kepuasan peserta pelatihan menyebutkan bahwa materi yang diberikan sangat mudah dipahami. Modul dapat memberikan dampak positif dalam pembelajaran dan pelatihan yag dilakukan, diantaranya : Memungkinkan peserta belajar mandiri sesuai kemampuan dan minatnya sehingga peserta pelatihan dapat belajar berkesinambungan walaupun program PKM ini sudah berakhir

\section{DAFTAR PUSTAKA}

Kurnia, I. (2013). Penerapan Model Pembelajaran Kooperatif tipe Snowball throwing untuk Meningkatkan Hasil Belajar PKN, Journal of Elementary Education, 2 (2), 25-29

Sagala, S. (2010). Konsep dan Makna Pembelajaran. Bandung: Alfabeta

Sardiman. A.M., (2004). Interaksi dan Motivasi Belajar Mengajar. Jakarta : Raja Grafindo Persada.

Susilofy. (2010). Online http://susilofy.wordpress.com/2010 /09/28/hakekat-belajar-prestasi 